\title{
Probability of bilateral disease in people presenting with a unilateral vestibular schwannoma
}

\author{
D G R Evans, R Lye, W Neary, G Black, T Strachan, A Wallace, R T Ramsden
}

Department of Medical Genetics, St Mary's Hospital, Manchester, UK

D G R Evans

G Black

A Wallace

Department of Otolaryngology W Neary

R T Ramsden

Department of Neurosurgery, Manchester Royal Infirmary, Manchester, UK

R Lye

\section{University}

Department of Human Genetics, Newcastle upon Tyne, UK

T Strachan

Correspondence to: Dr D G R Evans,

Department of Medical Genetics, St Mary's Hospital, Hathersage Road,

Manchester M13 0JH, UK.

Telephone 0044161276

6206; fax 0044161276 6145 .

Received 6 July 1998 and in revised form

30 November 1998

Accepted 10 December 1998

Table 1 Diagnostic criteria for NF2

Bilateral vestibular schwannomas or family history of NF2 plus

(1) unilateral vestibular schwannoma or

(2) Any two of: meningioma, glioma, neurofibroma, schwannoma, posterior subcapsular lenticular opacities.

Additional criteria

Unilateral vestibular schwannoma +any two of: meningioma, glioma, neurofibroma, schwannoma, posterior subcapsular lenticular opacities.

Multiple meningioma (two or more) + unilateral vestibular schwannoma or any two of: glioma, neurofibroma, schwannoma, cataract risk of harbouring an NF2 mutation in at least a proportion of their somatic cells. (F Neurol Neurosurg Psychiatry 1999;66:764-767)

Keywords: neurofibromatosis type 2; somatic mosaicism; mutation; vestibular schwannoma

Type 2 neurofibromatosis (NF2) is an autosomal dominant inherited condition characterised by development of bilateral vestibular schwannomas, schwannomas of other cranial, spinal, and cutaneous nerves, and cranial and spinal meningiomas. ${ }^{1-3}$ The National Institutes of Health (NIH) defined diagnostic criteria for NF2 in $1987^{4}$ and modified criteria to allow for sporadic cases have since been published. ${ }^{2}$ According to NIH criteria (table 1) a person with bilateral vestibular schwannomas is assumed to have NF2 and $50 \%$ of offspring would be predicted to be affected. As the isolation of the NF2 gene in $1993^{56}$ mutation studies have included reports of germ line mutations..$^{7-9}$ Detection rates using routine methodology have been disappointingly low even in classically affected patients and cannot therefore be used as a means of excluding the condition.

At presentation, $10 \%-20 \%$ of patients with NF2 have a unilateral vestibular schwannoma, although other features of the disorder may be identified. $^{2310}$ However, the clinical details of such patients have not been fully reported before now. Previously we reported a series of such patients with unilateral vestibular schwannomas and other features suggestive of NF2. ${ }^{11}$ The risk to a patient who presents with a sporadic unilateral vestibular schwannoma of developing further tumours is uncertain. Unless it can be minimised by exclusion of a germline mutation, such patients and their children may need ongoing screening. We have analysed a large group of patients with NF2 who had unilateral vestibular schwannomas to determine the risk of developing contralateral disease.

\section{Patients and methods}

Since 1989 our multidisciplinary team has ascertained cases of NF2 from throughout the United Kingdom, 296 cases fulfilling modified criteria for NF2 (table 1). Thirty four died before the study, 21 since referral. Two hundred and seventy five of 296 patients had a history of vestibular schwannomas (21 patients diagnosed on DNA analysis alone or fulfilled criteria in other ways), 240 had clinical details concerning the diagnosis of each vestibular 
Table 2 Age at onset of unilateral vestibular schwannoma and time to bilaterality in 45 patients with NF2

\begin{tabular}{|c|c|c|c|c|c|c|c|c|}
\hline \multirow[b]{2}{*}{ Patient } & \multicolumn{2}{|c|}{ Onset $H L$} & \multirow[b]{2}{*}{$\begin{array}{l}\text { Diagnosis } \\
\text { UVS }(y)\end{array}$} & \multirow[b]{2}{*}{$\begin{array}{l}\text { Current age } \\
\text { (y) }\end{array}$} & \multirow[b]{2}{*}{$\begin{array}{l}\text { Age at BVS } \\
\text { (y) }\end{array}$} & \multirow[b]{2}{*}{ Delay (y) } & \multirow[b]{2}{*}{ Other NF2 features } & \multirow[b]{2}{*}{ Mutation } \\
\hline & Years & Sex & & & & & & \\
\hline \multicolumn{9}{|c|}{ Sporadic: } \\
\hline 1 & 15 & $M$ & 15 & 16 & - & 1 & $1 \mathrm{M}, 3 \mathrm{Sp}$ & No \\
\hline 2 & 35 & $\mathrm{~F}$ & 36 & 38 & - & $2(3)$ & $2 \mathrm{M}, 2 \mathrm{Sp}$ & No \\
\hline 3 & 22 & $\mathrm{~F}$ & 22 & 26 & - & 4 & $2 \mathrm{Sp}$ & ND \\
\hline 4 & 27 & $\mathrm{~F}$ & 28 & 30 & - & 3 & $3 \mathrm{M}$ & No \\
\hline 5 & 19 & M & 20 & 20 & - & $1(2)$ & $1 \mathrm{M}, 1 \mathrm{Gl}$ & Yes \\
\hline 6 & 16 & $\mathrm{~F}$ & 29 & 37 & - & $8(11)$ & $2 \mathrm{M}, 2 \mathrm{Sp}$ & ND \\
\hline 7 & 25 & $M$ & 26 & 28 & - & $2(3)$ & $4 \mathrm{M}, 1 \mathrm{sp}$ & Yes \\
\hline 8 & 26 & $\mathrm{~F}$ & 26 & 29 & - & 3 & $2 \mathrm{M}, \mathrm{OM}$ & No \\
\hline 9 & 43 & $M$ & 50 & 51 & - & $1(8)$ & 8 cut & Yes \\
\hline 10 & 44 & $\mathrm{~F}$ & 46 & 47 & - & $1(3)$ & $3 \mathrm{M}$ & No \\
\hline 11 & 22 & M & 24 & 27 & - & $3(5)$ & $4 \mathrm{M}, 2 \mathrm{Sp}, \mathrm{Ep}$ & Yes \\
\hline 12 & 19 & $\mathrm{~F}$ & 38 & 46 & - & $8(27)$ & $3 \mathrm{M}$ & Yes \\
\hline 13 & 42 & $\mathrm{~F}$ & 43 & 49 & - & $6(7)$ & $3 \mathrm{M}$ & No \\
\hline 14 & 25 & $\mathrm{~F}$ & 25 & 30 & - & 5 & OM, 1Sp, XII & No \\
\hline 15 & 48 & $\mathrm{~F}$ & 49 & 53 & - & $4(5)$ & $5 \mathrm{M}, 1$ cut, $\mathrm{X}$ & ND \\
\hline 16 & 29 & $\mathrm{~F}$ & 28 & 33 & - & $5(4)$ & $1 \mathrm{sp}, 3 \mathrm{cut}, \mathrm{Ep}$ & No \\
\hline 17 & 57 & $\mathrm{~F}$ & 59 & 62 & - & $3(5)$ & $3 \mathrm{M}$ & No \\
\hline 18 & 29 & $\mathrm{M}$ & 39 & 54 & - & $15(25)$ & $2 \mathrm{Sp}$ & No \\
\hline 19 & 50 & $\mathrm{~F}$ & 50 & $56+$ & - & 6 & $3 \mathrm{M}, 2 \mathrm{cut}$ & No \\
\hline 20 & 34 & $\mathrm{~F}$ & 36 & 52 & 42 & $6(8)$ & Nil & No \\
\hline 21 & 44 & $\mathrm{~F}$ & 48 & 63 & 61 & $13(17)$ & Nil & ND \\
\hline 22 & 21 & $\mathrm{~F}$ & 23 & 52 & 45 & $22(24)$ & $1 \mathrm{Sp}$ & No \\
\hline 23 & 16 & $\mathrm{~F}$ & 16 & $20+$ & 18 & 2 & $5 \mathrm{M}, \mathrm{nSp}, \mathrm{Ep}$ & No \\
\hline 24 & 18 & M & 17 & 25 & 21 & $8(7)$ & $6 \mathrm{M}, 3 \mathrm{Sp}$ & Yes \\
\hline 25 & 24 & $M$ & 24 & 42 & 32 & 8 & Nil & No \\
\hline 26 & 23 & $M$ & 36 & 45 & 37 & $1(14)$ & $\mathrm{OM}, 6 \mathrm{M} \mathrm{Sp}$ & No \\
\hline 27 & 16 & $\mathrm{~F}$ & 22 & 37 & 29 & 7 (11) & Nil & No \\
\hline 28 & 15 & $\mathrm{~F}$ & 15 & 33 & 20 & $5(5)$ & $1 \mathrm{sp}, 2 \mathrm{M}$ & No \\
\hline 29 & 11 & M & 11 & 15 & 13 & 2 & $1 \mathrm{M}, 7$ cut, PLO & No \\
\hline 30 & 33 & $\mathrm{~F}$ & 36 & 44 & 40 & $4(7)$ & $2 \mathrm{M}$ & ND \\
\hline 31 & 6 & $\mathrm{~F}$ & 23 & 36 & 23 & $0(16)$ & $1 \mathrm{Sp}, 1 \mathrm{cut}$ & Yes \\
\hline 32 & 14 & $\mathrm{~F}$ & 16 & 25 & 23 & $7(9)$ & Nil & No \\
\hline \multicolumn{9}{|c|}{ Familial: } \\
\hline \multicolumn{9}{|c|}{ Affected child: } \\
\hline P1 & 28 & $M$ & 56 & 62 & 56 & $0(15)^{\star}$ & Nil & Yes \\
\hline P2 & 37 & $\mathrm{~F}$ & 53 & 62 & 57 & $4(20)$ & $4 \mathrm{M}, 1 \mathrm{Sp}$ & No \\
\hline P3 & 31 & $M$ & 36 & 49 & 45 & $9(14)$ & Nil & Yes \\
\hline P4 & 17 & M & 18 & 39 & 25 & $7(8)$ & $\mathrm{M}, \mathrm{Sp}, \mathrm{Gl}$ & Yes \\
\hline P5 & 27 & $M$ & 32 & 42 & 39 & $3(8)$ & $4 \mathrm{M}$ & Yes \\
\hline P6 & 27 & $\mathrm{~F}$ & 27 & 45 & 43 & 16 & $4 \mathrm{M}, 3 \mathrm{Sp}, \mathrm{PLO}$ & Yes \\
\hline \multicolumn{9}{|c|}{ Affected parent: } \\
\hline $\mathrm{C} 1$ & 19 & M & 18 & 22 & - & $4(3)$ & 3cut, $\mathrm{X}$ & Yes \\
\hline $\mathrm{C} 2$ & 29 & $\mathrm{~F}$ & 29 & 32 & - & 3 & Nil & Yes \\
\hline C3 & 13 & M & 11 & 17 & 16 & $5(3)$ & Nil & No \\
\hline $\mathrm{C} 4$ & 19 & M & 18 & 25 & 24 & $6(5)$ & Nil & Yes \\
\hline C5 & 14 & $\mathrm{~F}$ & 12 & 18 & 16 & $4(2)$ & 2ct, PLO & No \\
\hline C6 & 13 & $\mathrm{~F}$ & 20 & 26 & 22 & $2(9)$ & $1 \mathrm{M}, 6 \mathrm{cut}, \mathrm{PLO}$ & No \\
\hline $\mathrm{C} 7$ & 21 & $\mathrm{~F}$ & 27 & 33 & 29 & $2(7)$ & $3 \mathrm{M}, 4$ cut, PLO & Yes \\
\hline
\end{tabular}

$\mathrm{M}=$ meningioma; $\mathrm{OM}=$ optic nerve meningioma; cut=cutaneous tumours; $\mathrm{PLO}=$ posterior lenticular opacity; $\mathrm{Gl}=\mathrm{glioma}$; $\mathrm{Ep}=$ ependymoma; $\mathrm{Sp}=$ spinal tumours, $\mathrm{X}=$ cranial nerve tumour; $\mathrm{HL}=$ hearing loss.

(n) Symptomatic delay between ears in years.

^Symptomatic delay before onset of bilateral hearing loss.

schwannoma. Of patients presenting with symptomatic vestibular schwannoma to our neuro-otological unit from a defined region (north west England population 4.1 million) between May 1989 and May 1998, 26 of 500 (5.2\%) had bilateral disease.

We analysed patients presenting with a unilateral vestibular schwannoma-either those with initial CT or MRI showing evidence of unilateral involvement, or those with unilateral symptoms for more than 10 years before diagnosis. In the second group delay in diagnosis between sides was defined. Other features of NF2 such as family history, other neurogenic tumours, cataracts, and cutaneous findings such as cafe au lait patches were noted and DNA from peripheral blood was analysed for mutations in the NF2 gene using methodology previously described. ${ }^{8}$ In patients in whom a mutation was not identified tumour material was subjected to molecular analysis. For all patients age at follow up was taken as the last detailed clinical examination or scan.

\section{Results}

Forty five of $240(18.2 \%)$ patients with NF2 fulfilling modified criteria for NF2 have experienced a delay in the onset of vestibular schwannomas on each side (table 2). According to NIH criteria 26 of 221 (12\%) had such a delay. In all but two patients (sporadic 31 and P1) the initial scan showed unilateral involvement. However, in both these patients the delay in symptoms between each side was longer than 10 years: it is likely that an early scan would have shown unilateral involvement. The mean delays and the ranges of delay for those developing bilateral tumours are presented in table 3

Neurofibromatosis type 2 affects males and females equally and the male:female ratio in the overall NF2 dataset was, as expected 1:1. However, of 32 sporadic patients with unilateral tumours there was a male:female ratio of 10:22 compared with $7: 6$ in the familial patients $\left(\chi^{2}=1.16, p=0.28\right)$. Although there was no skewing for most other features of the condition, 
Table 3 Mean age at hearing loss and interval between diagnosis in sporadic and familial cases

\begin{tabular}{|c|c|c|c|c|c|c|}
\hline & \multirow[b]{2}{*}{$M / F$} & $\begin{array}{l}\text { Age (y) } \\
H L\end{array}$ & $\begin{array}{l}\text { Age (y) } \\
V S\end{array}$ & $F U(y)$ & \multirow{2}{*}{$\begin{array}{l}\text { Interval 1st } \\
\text { to } 2 \text { nd }\end{array}$} & \multirow{2}{*}{$\begin{array}{l}\text { Mutation } \\
\text { detected } \\
\text { Yes/No }\end{array}$} \\
\hline & & \multicolumn{3}{|c|}{ Mean (range) } & & \\
\hline \multicolumn{7}{|l|}{ Sporadic: } \\
\hline $\begin{array}{l}\text { UVS } \\
\text { (S1-19) }\end{array}$ & $6 / 13$ & $\begin{array}{l}31.2 \\
(15-57)\end{array}$ & $\begin{array}{l}34.4 \\
(15-59)\end{array}$ & $\begin{array}{l}4.2 \\
(1-15)\end{array}$ & - & $5 / 11$ \\
\hline $\begin{array}{l}\text { BVS } \\
\text { (S20-32) }\end{array}$ & $4 / 9$ & $\begin{array}{l}21.6 \\
(6-44)\end{array}$ & $\begin{array}{l}25.1 \\
(11-48)\end{array}$ & $\begin{array}{l}12.9 \\
(4-29)\end{array}$ & $\begin{array}{l}6.4 \\
(0-22)\end{array}$ & $2 / 9$ \\
\hline \multicolumn{7}{|l|}{$\begin{array}{l}\text { Familial: } \\
\text { BVS }\end{array}$} \\
\hline $\begin{array}{l}\text { Parent } \\
\text { (P1-6) }\end{array}$ & $4 / 2$ & $\begin{array}{l}27.8 \\
(17-37)\end{array}$ & $\begin{array}{l}37.0 \\
(18-56)\end{array}$ & $\begin{array}{l}12.8 \\
(6-21)\end{array}$ & $\begin{array}{l}6.5 \\
(0-16)\end{array}$ & $5 / 1$ \\
\hline $\begin{array}{l}\text { Child } \\
\text { (C3-7) }\end{array}$ & $2 / 3$ & $\begin{array}{l}16.0 \\
(13-21)\end{array}$ & $\begin{array}{l}17.6 \\
(11-27)\end{array}$ & $\begin{array}{l}6.0 \\
(5-7)\end{array}$ & $\begin{array}{l}3.8 \\
(2-6)\end{array}$ & $2 / 3$ \\
\hline \multicolumn{7}{|l|}{ UVS: } \\
\hline $\begin{array}{l}\text { Child } \\
\text { (C1-2) }\end{array}$ & $1 / 1$ & $\begin{array}{l}24 \\
(19-29)\end{array}$ & $\begin{array}{l}23.5 \\
(18-29)\end{array}$ & $\begin{array}{l}3.5 \\
(3-4)\end{array}$ & - & $2 / 0$ \\
\hline
\end{tabular}

Table 4 NF2 mutations identified in 45 patients with NF2 presenting with unilateral vestibular schwannoma

\begin{tabular}{|c|c|c|c|}
\hline \multicolumn{2}{|c|}{ Individual mutation } & Exon & $\begin{array}{l}\text { UVS } \\
B V S\end{array}$ \\
\hline \multicolumn{4}{|c|}{ Nonsense mutations: } \\
\hline S5 & G100>T, Glu34>stop & 1 & UVS \\
\hline S9 & $\mathrm{C} 784>\mathrm{T}, \operatorname{Arg} 262>$ stop & 8 (mosaic) & UVS \\
\hline $\mathrm{S} 24$ & C169>T, Arg57>stop & 2 & BVS \\
\hline $\mathrm{S} 31$ & $\mathrm{C} 1612>\mathrm{T}, \mathrm{G} \ln 538>$ stop & 15 & BVS \\
\hline P3 & G1570>T, Glu524>stop & 14 & BVS \\
\hline P5 & $\mathrm{C} 1408>\mathrm{T}, \mathrm{G} \ln 470>$ stop & 13 & BVS \\
\hline P6 & C784>T, Arg262>stop & 8 (mosaic) & BVS \\
\hline $\mathrm{C} 4$ & G1570>T, Glu524>stop & 14 & BVS \\
\hline \multicolumn{4}{|c|}{ Frameshifting deletions: } \\
\hline S7 & 40 delCT & 1 & BVS \\
\hline C7 & 855 delT & 9 & BVS \\
\hline \multicolumn{4}{|c|}{ Frameshifting insertions: } \\
\hline S11 & 1191 ins T & 12 & UVS \\
\hline \multicolumn{4}{|c|}{ Missense: } \\
\hline S12 & A317>G, Glu106>Gly & 3 & UVS \\
\hline $\mathrm{P} 4$ & $\mathrm{C} 1055>\mathrm{T}$, Thr352>Met & 11 & BVS \\
\hline $\mathrm{C} 2$ & T1604>C, Leu535>Pro & 15 & UVS \\
\hline \multicolumn{4}{|c|}{ Splice site: } \\
\hline P1 & $516+1 \mathrm{G}>\mathrm{A}$ & 5 & BVS \\
\hline $\mathrm{C} 1$ & $676-7 \mathrm{~T}>\mathrm{G}$ & 8 & UVS \\
\hline
\end{tabular}

BVS=Bilateral vestibnular schwannoma; UVS=unilateral vestibnular schwannoma.

13 of the 22 females (59\%) had two or more meningiomas at diagnosis of the unilateral vestibular schwannomas whereas only four of 10 men did so $(40 \% ; p=0.5)$. Furthermore, of 21 patients who remained with unilateral tumours, meningiomas were even more overrepresented among women with 10 of 12 having two or more.

Presymptomatic people among the familial group with affected parents were analysed for laterality of diagnosis. Four of seven had presymptomatic unilateral tumours detected on MRI of whom two patients are still to develop contralateral tumours 3-4 years after diagnosis.

Mutations of all varieties except large deletions have been identified (table 4). Mutations were detected in only $26 \%$ (seven of 27 ) of the sporadic patients compared with $69 \%$ (nine of 13) of the familial patients. Within the sporadic group $59 \%$ (16 of 27 ) did not fulfil $\mathrm{NIH}$ criteria and mutations were detected in $31 \%$ (five of 16 ). Mutation detection was successful in only $18 \%$ (two of 11 ) of those fulfilling the criteria. Tumours from patients S9, S10, S18, and S19 were subjected to molecular analysis and both mutational events in the NF2 gene were identified in S9 and S18. A second tumour from S9 showed an identical nonsense mutation to the first (table 4).

\section{Discussion}

There is a low but significant risk that a person presenting with a unilateral vestibular schwannoma will eventually develop a contralateral tumour (or other related tumours) and some means by which those people who are at high risk could be identified would be extremely valuable. The results of surgery are much improved by the smaller size of tumour at operation, ${ }^{10}{ }^{12}{ }^{13}$ and an indication that a patient is likely to develop a contralateral tumour may even influence the type of surgery or other treatment for the initial side. ${ }^{10}{ }^{14}$ Relatives may also benefit from screening and genetic counselling. We have highlighted some factors useful for identification of those at risk of further tumours.

It will always remain a matter for speculation whether certain patients (for example, patients S1-19) actually have NF2 and will develop bilateral disease. However, it must be realised that these patients are indistinguishable at the time of presentation. In our survey, even excluding those diagnosed presymptomatically through affected parents, over half of those who presented with a unilateral vestibular schwannoma developed a contralateral tumour. Therefore given the relatively short follow up time in S1-19 many of these patients may yet develop a contralateral tumour.

The predominance of females in the sporadic group may be due to the increased frequency of meningiomas in females with NF2. ${ }^{15}$ However, it raises the possibility that there is a higher risk of meningiomas among females with mosaic NF2 who would seem to be more likely to present with a unilateral tumour and meningiomas than any other combination.

Mutation analysis is a useful additional investigation but it is not as valuable as detailed clinical assessment in reducing risk estimates of developing a contralateral tumour in those with unilateral disease. Of seven patients without other features of NF2 at presentation only two (P1 and P3) had an identifiable mutation. Low mutation detection rates $(40 \%-60 \%)$ have been reported several times. ${ }^{7-9} 1617$ Although the mutation detection rate is generally low it is of note that it was higher at five of $16(31 \%)$ in sporadic unilateral patients compared with two of $11(18 \%)$ in the sporadic patients who went on to develop bilateral disease. The high detection rate in the familial group (nine of $13 ; 70 \%$ ) is in keeping with previous reports in which a significant $(20 \%)$ difference was noted in the likelihood of detection between familial and sporadic patients with classic bilateral disease (55\% and $36 \%$ respectively). ${ }^{18}$ We hypothesised that this difference is due to somatic mosaicism with the NF2 mutation being present in only a proportion of somatic cells. This was the case for patient P6 in whom the mutation was present in only $37 \%$ of lymphocytes. ${ }^{19} \mathrm{~A}$ mutation which is present in an insufficient proportion of cells to detect in lymphocyte DNA may nevertheless be found 
Table 5 Average risk per decade of patients presenting with vestibular schwannoma having NF2

\begin{tabular}{llll}
\hline Age $(y)$ & \% with NF2 & $\begin{array}{l}\text { \% with NF2 UVS at } \\
\text { diagnosis }\end{array}$ & $\begin{array}{l}\text { \% with NF2 with no FH and } \\
\text { no other NF2 features }\end{array}$ \\
\hline $10-19$ & $33 \%(22-50 \%)$ & $6 \%(2.6-9 \%)$ & $1 \%(0.3-1.4 \%)$ \\
$20-29$ & $15 \%(8-22 \%)$ & $2.7 \%(0.9-4 \%)$ & $0.45 \%(0.1-0.6 \%)$ \\
$30-39$ & $5 \%(3-8 \%)$ & $0.9 \%(0.3-1.4 \%)$ & $0.15 \%(0.03-2.2 \%)$ \\
$40-49$ & $2 \%(1-3 \%)$ & $0.36 \%(0.1-0.54 \%)$ & $0.06 \%(0.01-0.08 \%)$ \\
$50-59$ & $1 \%(0.5-1.5 \%)$ & $0.18 \%(0.06-0.27 \%)$ & $0.03 \%(0.007-0.05 \%)$ \\
$60-69$ & - & - & - \\
\hline
\end{tabular}

UVS = unilateral vestibular schwannoma; $\mathrm{FH}=$ family history.

as an identical mutation in all tumours from the same patient (for example, case S9). In addition, previous mutation studies on tumours from those with unilateral vestibular schwannomas and other features of $\mathrm{NF}^{20}$ have shown that unless the modified criteria for NF2 are met such patients are unlikely to have a detectable NF2 mutation in blood even when both mutational events were detected in the tumour. Therefore, if mutation analysis is carried out on patients with unilateral vestibular schwannomas (with or without other features of NF2) analysis of tumour DNA is likely to be more reliable than lymphocytic DNA. However, most patients who do not fulfil modified criteria probably represent either chance associations or low level mosaicism, in which the risk of bilateral disease is small.

Of patients with vestibular schwannomas $4 \%-5 \%{ }^{10}{ }^{21}$ have NF2 and from our survey of patients with NF2, $12 \%-18 \%$ are likely to present initially with a unilateral tumour. Thus $<1 \%$ of patients with unilateral vestibular schwannomas will go on to develop a contralateral tumour. However, of those presenting with a unilateral tumour in this series only seven of 45 had neither an affected parent with NF2 nor other tumours strongly suggestive of the condition. Therefore, after a careful clinical examination for cutaneous tumours and review of a cranial and upper cervical MR less than one in every 500 patients with an isolated unilateral vestibular schwannoma will develop a contralateral tumour.

It is possible to age stratify the risk of a patient with unilateral disease becoming bilateral. Table 5 shows the average risk of a patient with a vestibular schwannoma having NF2 for each decade of age at presentation. ${ }^{10}$ By taking $3 \%$ of this risk ( $18 \%$; seven of 45$)$ the chances of a patient developing a contralateral tumour can be derived (table 5). This does not allow for the possibility that not all our patients in table 2 would have eventually developed a contralateral tumour and that more subtle signs of NF2 may have been present at the initial presentation of some of the seven patients with apparently unilateral sporadic vestibular schwannomas. The real risk may, therefore, be even smaller.

\section{Conclusions}

The risks for a patient presenting with a unilateral vestibular schwannoma developing bilateral disease are low. In patients over 35 years of age with no relevant family history and no other tumour features of NF2 the risks are insufficient to warrant further follow up for patient or family. A detailed cutaneous and ophthalmic examination in those under 35 years may detect further patients who require monitoring. Risks to young patients ( $<20$ years old) can probably be further modified by molecular analysis of blood and, in particular, tumour material. Overall probably less than $2 \%$ of those with unilateral vestibular schwannoma at presentation require ongoing screening for themselves or their offspring.

This research has been funded by grants from the UK Neurofibromatosis Association, Medical Research Council and from the North West Regional Health Authority. We thank the many clinicians who have sent us details of their patients with NF2.

1 Kanter WR, Eldridge R, Fabricant R, et al. Central neurofibromatosis with bilateral acoustic neuroma. Genetic, clini$\mathrm{cal}$ and biochemical distinctions from peripheral neurofibromatosis. Neurology 1980;30:851-9.

2 Evans DGR, Huson SM, Donnai D, et al. A clinical study of type 2 neurofibromatosis. Q F Med 1992;84:603-18.

3 Parry DM, Eldridge R, Kaiser-Kupfer MI, et al. NeurofiParry DM, Eldridge R, Kaiser-Kupfer MI, et al. Neurofi-
bromatosis 2 (NF2): clinical characteristics of 63 affected bromatosis 2 (NF2): clinical characteristics of 63 affected
individuals and clinical evidence for heterogeneity. $A m \mathcal{F}$ Med Genet 1994;52:450-1.

4 National Institutes of Health Consensus Development Conference Statement on Neurofibromatosis. Neurofibromatosis Research Newsletter 1987;3:3-6.

5 Rouleau GA, Merel P, Lutchman M, et al. Alteration in a new gene encoding a putative membrane-organizing protein causes neuro-fibromatosis type 2. Nature 1993:363; 515-21.

6 Troffater JA, MacCollin MM, Rutter JL, et al. A novel moesin-, ezrin-, radixin-like gene is a candidate for the 800.

7 MacCollin M, Ramesh V, Jacoby LB, et al. Mutational analysis of patients with neurofibromatosis 2 . Am f Hum Genet 1994;55:314-20.

8 Bourn D, Carter SA, Mason S, et al. Germline mutations in the neurofibromatosis type 2 tumour suppressor gene. Hum Molec Genet 1994;5:813-6.

9 Merel P, Hoang-Xuan K, Sansom M, et al. Screening for germ-line mutations in the NF2 gene. Genes Chromosomes Cancer 1995;12:117-27.

10 Evans DGR, Ramsden R, Huson SM, et al. Type 2 neurofibromatosis: the need for supraregional care. $f$ Laryngol Otol 1993;107:401-6.

11 Neary W, Newton VE, Laiode-Kemp SN, et al. A clinical, genetic and audiological study of patients with unilateral vestibular schwannomas. I. Clinical features of neurofibromatosis in patients with unilateral vestibular schwannomas. F Laryngol Otol 1996;110:634-40.

12 Martuza RL, Ojemann RG. Bilateral acoustic neuromas: clinical aspects, pathogenesis and treatment. Neurosurgery 1982;10:1-12.

13 Samii M, Matthies C, Tatagiba M. Management of vestibular schwannomas (acoustic neuromas): auditory and facial nerve function after resection of 120 vestibular schwannomas in patients with neurofibromatosis 2. Neurosurg 1997; 40:696-706

14 Evans DGR, Huson SM, Donnai D, et al. A genetic study of type 2 neurofibromatosis: II Guidelines for genetic counselling. F Med Genet 1992;29:847-52.

15 Evans DGR, Blair V, Strachan T, et al. Variation in expression of the gene for type 2 neurofibromatosis: absence of a gender effect on vestibular schwannoma. $\mathcal{f}$ Otolaryngol 1995;109:830-5.

16 Parry DM, MacCollin M, Kaiser-Kupfer MI, et al. Germ-line mutations in the neurofibromatosis 2 gene: correlations with disease severity and retinal abnormalities. Am F Hum Genet 1996;59:529-39.

17 Ruttledge MH, Andermann AA, Phelan CM, et al. Type of mutation in the neurofibromatosis type 2 gene (NF2) frequently determines severity of disease. Am f Hum Genet frequently determ

18 Evans DGR, Truman L, Wallace A, et al. Mosaicism in classical NF2: a common mechanism for sporadic disease in tumour prone syndromes?. Am f Hum Genet 1998; (in press).

19 Biljsma EK, Wallace A, Evans DGR. Misleading linkage analysis in an NF2 presymptomatic test owing to mosaicism. F Med Genet 1997;34:934-6.

20 Wu C-L, Thakker N, Neary W, et al. Differential diagnosis of type 2 neurofibromatosis: molecular discrimination of NF2 and sporadic vestibular schwannoma. $\mathcal{f}$ Med Genet 1998; (in press).

21 Tos M, Thomsen J. Epidemiology of acoustic neuromas. $\mathcal{F}$ Laryngol Otol 1984;98:685-92. 